\title{
A theoretically informed survey of the views and experiences of practicing pharmacists on
} research conduct, dissemination and translation.

STEWART, D., CUNNINGHAM, S., STRATH, A., MACLURE, A., GIBSONSMITH, K., RUSHWORTH, G.F., DREISCHULTE, T., NICOLSON, C., PFLEGER, D., TIERNAN, D., MACLURE, K. 


\section{Title Page}

\section{A theoretically informed survey of the views and experiences of practicing pharmacists on research conduct, dissemination and translation}

\section{Derek Stew arta ${ }^{a}$ Scott Cunninghama ${ }^{a}$ Alison Strath ${ }^{b}$, Andrew MacLurea, Kathrine Gibson-Smitha, Gordon Rushworthc, Tobias Dreischulted, Christopher Nicolsone, David Pflegerf, Dawn Tiernang, Katie MacLure ${ }^{a}$}

Derek Stewart, aSchool of Pharmacy and Life Sciences, Robert Gordon University, The Sir Ian Wood Building, Garthdee Road, Aberdeen, UK. AB10 7GJ . d.stewart@rgu.ac.uk

Scott Cunningham, aSchool of Pharmacy and Life Sciences, Robert Gordon University, The Sir Ian Wood Building, Garthdee Road, Aberdeen, UK. AB10 7GJ .

s.cunningham@rgu.ac.uk

Alison Strath, aSchool of Pharmacy and Life Sciences, Robert Gordon University, The Sir Ian Wood Building, Garthdee Road, Aberdeen, UK. AB10 7GJ . a.strath@rgu.ac.uk

Andrew MacLure, aSchool of Pharmacy and Life Sciences, Robert Gordon University, The Sir Ian Wood Building, Garthdee Road, Aberdeen, UK. AB10 7GJ .

a.k.maclure1@rgu.ac.uk

Kathrine Gibson-Smith, aSchool of Pharmacy and Life Sciences, Robert Gordon University, The Sir Ian Wood Building, Garthdee Road, Aberdeen, UK. AB10 7GJ . k.l.gibson-smith@rgu.ac.uk

Gordon F Rushworth, CHighland Pharmacy Education and Research Centre, Centre for Health Science, Old Perth Road, Inverness, UK. IV2 3J H. gordon.rushworth@nhs.net Tobias Dreischulte, dPharmacy Department, NHS Tayside, Kings Cross Hospital, Clepington Road, Dundee, UK. DD3 8EA. t.dreischulte@dundee.ac.uk

Christopher Nicolson, eNHS Orkney/Shetland, Gilbert Bain Hospital, South Road, Lerwick, Shetland, ZE1 0TB. christophernicolson@nhs.net

David Pfleger, ${ }^{\text {f }}$ Pharmacy \& Medicines Directorate, Westholme, Woodend Hospital, Queens Road, Aberdeen, UK. AB15 6LS. david.pfleger@nhs.net

Dawn Tiernan, gPharmacy Department, Western I sles Hospital, MacAulay Road, Stornoway, Isle of Lewis, UK. HS1 2AF. dawn.tiernan@nhs.net Katie MacLure, aSchool of Pharmacy and Life Sciences, Robert Gordon University, The Sir Ian Wood Building, Garthdee Road, Aberdeen, UK. AB10 7GJ . k.m.maclure@rgu.ac.uk 
Corresponding author, Professor Derek Stewart 


\section{A theoretically informed survey of the views and experiences of practicing pharmacists on research conduct, dissemination and translation}

\section{Abstract \\ Background}

While studies have reported pharmacists' perspectives of research involvement, almost all are limited by sector, have little focus on research translation and have not incorporated behaviour change theory.

\section{Objective}

To determine pharmacists' views and experiences of research conduct, dissemination and translation

\section{Methods}

This was an electronic cross-sectional survey of pharmacists across six Scottish health board areas. Survey items were: demographics; research activities (e.g. conduct, dissemination) in the last two years; research interests, experience and confidence in research tasks (e.g. proposal writing, data collection); and Likert statements on research conduct and dissemination, and translating research findings to practice.

Conduct/dissemination and translation items were based on the Theoretical Domains Framework (TDF). Data were analysed using descriptive and inferential statistics, and principal component analysis (PCA) of TDF items. Following determination of internal consistency, scores for each component were calculated.

\section{Results}

The response rate was $19.4 \%$ (136/701), with 17 (12.5\%) currently involved in research. Responses were more positive for interest in research than experience or confidence. PCA of research conduct/dissemination items identified three internally reliable components of support/opportunities, motivation/outcomes, and roles/characteristics. Component scores for support/opportunities to participate in research were most negative. PCA of translation items identified three internally reliable components of current practices/abilities, consequences and support. Scores for all three components were positive, being most positive for consequences of research translation. Those in secondary care, with a postgraduate qualification and prescribers scored higher for interest, experience, confidence, and for most components $(p<0.05)$. 


\section{Conclusion}

A minority of pharmacists are involved in the research conduct/dissemination and these are more likely to be highly qualified individuals based in secondary care. Given the need to develop and evaluate new models of pharmaceutical care, involvement should be extended to all practice settings. Study findings could be used to develop behaviour change interventions targeting individuals and organizations.

\section{Keywords}

pharmacists; questionnaire; research capacity; research translation; Scotland 


\section{A theoretically informed survey of the views and experiences of practicing pharmacists on research conduct, dissemination and translation}

\section{Introduction}

The Sicily Statement defining evidence-based practice (EBP) describes five key steps of: translation of uncertainty to an answerable question; systematic retrieval of best evidence; critical appraisal for validity, clinical relevance and applicability; application; and performance evaluation. ${ }^{1}$ EBP is therefore dependent on the conduct and dissemination of research, and translation to practice. While it is unreasonable to expect all practising pharmacists to be involved in research conduct or dissemination, more may require to translate research findings (e.g. changes in the pharmacotherapy evidence base for acute and chronic conditions) to their practice. The relevance of research to pharmacy practice is well-recognized at national and international levels, being emphasized in policy and practice statements of key pharmacy organizations (Table 1 ).

$<$ Insert Table 1 here $>$

Research capacity, defined as 'enhancing the abilities of individuals, organizations and systems to undertake and disseminate high quality research effectively and efficiently. 'Given the emphasis on research in pharmacy policy and practice statements and that capacity relates to the development of individuals and organizations, further consideration of capacity building is warranted. ${ }^{7}$ A systematic review of the peer reviewed literature (1990-2014) synthesised pharmacists' views and attitudes around involvement in practice research, and associated barriers and facilitators. ${ }^{8}$ The key findings were that while participants recognized the value of practice based research, factors such as time, research training and support were key limitations to their involvement. Since 2014, a number of similar studies have explored views and attitudes of pharmacists towards practice research, with generally similar findings. ${ }^{9-17}$ Whilst acknowledging this accumulation of evidence, there are several key weaknesses to these studies. Almost all have focused on aspects of research conduct in one practice setting, and only one survey from Malaysia reporting data on research translation, with higher educational level linked to higher translation. ${ }^{18}$

One further key limitation of the evidence base derived from these studies is the omission of inclusion of comprehensive behavior change theories (i.e. those which explain why behaviour changes or not) within the stages of research design, data collection, analysis and interpretation. Considering theory in research processes enhances robustness and rigour, and the relevance and impact of the findings. ${ }^{19}$ Incorporation of behavior change theory also permits the identification of possible theoretical mechanisms of behavior change leading to the development of targeted 
intervention(s). ${ }^{20}$ It is claimed that these interventions are more likely to be effective in altering behavior compared to more pragmatic approaches. ${ }^{21}$

In Scotland in 2017 the Chief Pharmaceutical Officer of the Scottish Government launched a refreshed strategy for the profession, 'Achieving Excellence in Pharmaceutical Care'. ${ }^{22}$ The two key priorities are

i. improving pharmaceutical care, thus delivering safer use of medicines for the people of Scotland

ii. enabling pharmaceutical care transformation by ensuring capability and capacity by further developing the pharmacy workforce, developing a digitally enabled infrastructure, and planning and delivery requirements for sustainable pharmaceutical care services.

The need for services to be systematically developed, implemented and evaluated is articulated throughout the strategy, including the need to involve practicing pharmacists in both research conduct and translation of findings. The tasks involved in such service advances are likely to be resource intensive, particularly when undertaken at scale in an organization or across organizations. Robust, rigorous pharmacy practice research should therefore be a key focus for all stages of developing new services and interventions, implementing to practice settings and evaluating to ensure that desired outcomes (clinical, humanistic and economic) are achieved. With only one qualitative study of pharmacists' perceptions of pharmacist-led research in one geographical area of Scotland ${ }^{9}$, there is a need to apply behavior change theory to study the involvement of practicing pharmacists in Scotland in the conduct, dissemination and translation of research findings.

The aim of this study was to determine pharmacists' views and experiences of research conduct, dissemination and translation. 


\section{Method}

Design

The design was a cross-sectional survey using an online questionnaire.

Setting

The study took place from May to November 2017 across the six most northern, remote and rural health board areas in Scotland accounting for around 30\% of pharmacists in Scotland.

Questionnaire development and testing

The draft questionnaire was based on one previously used by members of the research team, ${ }^{10}$ with contextualisation for practice in Scotland and the addition of items derived from behaviour change theory. The draft questionnaire was reviewed for face and content validity by several academics, researchers and practicing pharmacists. Items were in domains of: demographics (12 items); research activities in the last two years (4 items); research interests, experience and confidence (48 items); research conduct and dissemination ( 33 items); translating research ( 21 items); readiness to participate in research ( 1 item); research training ( 2 items); and research plans and areas of interest (2 items). Question types were a combination of closed, 5-point Likert scales and open to allow detailed comment. Items were based on several theoretical frameworks. Those on conduct, dissemination, and translation were based on the Theoretical Domains Framework (TDF) which includes constructs from 33 behavior change theories. ${ }^{23}$ The domains (i.e. the determinants of behaviour) are: knowledge; skills; social/professional role and identity; beliefs about capabilities; optimism; beliefs about consequences; reinforcement; intentions; goals; memory, attention and decision processes; environmental context and resources; social influences; emotions; and behavioral regulation. The Determinants of Implementation Behavior Questionnaire, which incorporates the TDF domains, was used as a basis for the development of the individual items. ${ }^{24}$ Readiness to participate in research was categorised according to the Stage of Change model of 'precontemplation', 'contemplation', 'preparation' and 'action'. ${ }^{25}$ In the demographics section, respondents classified themselves as innovators, early adopters, early majority, late majority and laggards based on receptivity to change, using the item wording as described by Rogers. ${ }^{26}$ Given the previous use of a similar questionnaire, ${ }^{10}$ no pilot stage was conducted. The questionnaire was developed in SurveyMonkey $\odot$ and tested for compatibility with platforms (PC, tablet, smartphone), browsers and NHS email and internet filters. 
Recruitment and data collection

An email was sent, by either the health board Director of Pharmacy or the lead research pharmacist, to all pharmacists registered with the General Pharmaceutical Council practicing in any primary or secondary care setting. The email contained a link to the participant information leaflet and the questionnaire. Evidence based strategies were employed to maximise the response rate, ${ }^{27}$ including providing: an information leaflet outlining the study aim, potential benefits and assured anonymity; a visually attractive questionnaire; and two follow-up email reminders.

Analysis

Descriptive analysis was undertaken for: demographics; research activities; research interest, experience and confidence; views on research conduct, dissemination and translation; and readiness to participate in research and research training. Internal consistencies of responses on interest, experience and confidence were tested using Cronbach's alpha, aiming for values $\geq 0.7 .^{28}$ Total scores (median and interquartile range $(I Q R)$ ) for each scale were obtained by assigning values ( $1=$ no to $5=$ very). Differences in total scores of interest, experience and confidence were tested using Friedman's two way analysis of variance by ranks. Correlation between overall scores of interest/experience, interest/confidence and experience/confidence were assessed using Spearman's rho. Relationships between demographic variables and scores were tested using Mann-Whitney $U$ test ( 2 groups) and Kruskall-Wallis ( $>2$ groups). P-values $\leq 0.05$ were considered to be statistically significant.

I tems measured relating to views on research conduct, dissemination and translation were subjected to principal components analysis (PCA) to reduce the large number of items to a smaller number of components. ${ }^{29}$ Orthogonal (Varimax) rotation was performed initially to aid in the interpretation of the components, and the results were compared to oblique (Promax) rotation. The number of components retained was based on the Kaiser criterion (Eigenvalues $>1$ ), visual inspection of the scree plot and meaningfulness of the results according to the theoretical framework. The analysis included items that were not freestanding, cross-loading or decreasing the scale's internal reliability, and that displayed acceptable communalities, with factor pattern/structure coefficients above 0.4. In performing PCA, the Kaiser-Meyer-Olkin (KMO) measure of sampling adequacy and the Bartlett's Test of Sphericity were used to assess the suitability of the sample for PCA. ${ }^{29}$ Following determination of internal consistencies, total scores (median and interquartile range, IQR) were obtained by assigning scores of 1 (strongly disagree) to 5 (strongly agree) to each of the Likert statement responses and each compared to the scale midpoint. Inferential analysis 
(Mann-Whitney U, Kruskal-Wallis) was used to explore any relationship between demographic variables and component scores.

Research readiness and research training were both summarised in two categories: those 'not ready' (I have never thought about being involved in research/ I have thought about being involved in research but have taken no action, and I have never thought about research training / I have thought about research training but have taken no action) and the remainder, 'ready'. Variables significantly associated with readiness were identified using Chi-square.

Content analysis was independently performed by two members of the research team on the responses to the open questions, looking for patterns, similarities and differences. ${ }^{30}$ Ethical approval

The study was approved by a university ethics review committee and was considered exempt from NHS ethical review. Management approval was obtained from the Research and Development committees of each of the six participating health boards (NRS17/219303). Return of the questionnaire was deemed an indication of consent to participate. 


\section{Results}

Response rates

Of the 172 responses, 36 had completed only the demographics section and were removed from any further analysis, giving a response rate of $19.4 \%$ (136/701).

Responses rates across each of the health boards varied from $15.1 \%(40 / 265)$ to $50.0 \%$ $(6 / 12)$.

Personal and practice demographics

Respondent demographics are given in Table 2. Most were female (76.5\%, $n=104)$, with two thirds aged $<45$ years $(66.2 \%, \mathrm{n}=90)$ with $<20$ years' experience as pharmacists (64.7\%, $n=88)$. Around half were working full-time $(57.6 \%, n=92)$, had a postgraduate qualification $(58.1 \%, n=79)$ and were registered prescribers $(50.7 \%, n=69)$. Secondary care was the most common sector of practice $(41.2 \%, n=56)$. In terms of receptivity to change, more than half $(58.8 \%, n=80)$ classified themselves as innovators and early adopters, and none as laggards.

$<$ Insert Table 2 here $>$

Research involvement

Over the preceding two years, $54(39.7 \%)$ had participated in research, $31(22.8 \%)$ had conducted research, 16 (11.8\%) had presented research at a national or international conference and $11(8.1 \%)$ had published research in a peer-reviewed journal.

Research interest, experience and confidence

Responses to items on interest, experience and confidence are given in Table 3.

$<$ Insert Table 3 here $>$

The Cronbach's alpha internal consistencies of the three scales of interest, experience and confidence were all $0.96,0.96$ and 0.97 respectively indicating high internal reliability. The median summary score (range possible 16-80, scale mid-point 48; high scores positive) for research interest was 50 (IQR 41.25-61), research experience 38.5 (IQR 28-46.25) and research confidence 42 (IQR 32.25-51.75). Summary scores for interest were significantly higher than confidence which were significantly higher than experience $\left(x^{2}, p<0.001\right)$. There were positive correlations between total scores for interest and experience, interest and confidence, and confidence and experience (Spearman's rho, $\mathrm{p}<0.001$ ) with those more interested also more experienced and confident. Moderately high levels of interest were reported for all items other than 'writing a research proposal' (51.5\%, $n=70$ reporting little or no interest). More than two thirds had little or no experience of: 'conducting a systematic review' $(69.1 \%, n=94)$; 
'using qualitative research methods' (68.4\%, $n=93$ ) 'giving an oral presentation at national or international conferences' $(69.1 \%, n=94)$; and 'writing and publishing research in academic journals' $(79.5 \%, n=108)$. More than two thirds of the respondents had little or no confidence in writing and publishing research in academic journals' (72.1\%, $n=98)$.

Scores of interest were significantly higher (thus more positive) for respondents who had been registered as pharmacists for $11-20$ years (Kruskal-Wallis, $p<0.05$ ), those with a postgraduate qualification (Mann-Whitney $U, p<0.005$ ) and those who considered themselves to be either innovators/early adopters (Mann-Whitney $U, p=0.001$ ). Scores of experience were similarly significantly higher for those registered as pharmacists for 11-20 years (Kruskal-Wallis, $\mathrm{p}<0.005$ ), with a postgraduate qualification (Mann-Whitney $U, p<0.001$ ), registered prescribers (Mann-Whitney $U, p<0.001$ ) and those innovative or role models (Mann-Whitney $U, p=0.001$ ). For confidence, scores were significantly higher for those registered as pharmacists for 11-20 years (Kruskal-Wallis, $p<0.005$ ), possessing a postgraduate qualification (Mann-Whitney $U, p<0.001$ ), registered prescribers (Mann-Whitney $U, p<0.001$ ) and innovators/early adopters (Mann-Whitney $U, p<0.005)$.

Participation in research

One hundred and twenty-four respondents completed all items relating to views on participation (conduct/dissemination) in research. When these items were subjected to PCA, the correlation matrix contained multiple coefficients above 0.3. The Kaiser-MeyerOlkin measure of sampling adequacy (0.88) and Bartlett's test of sphericity (significance $<0.001$ ) confirmed the factorability of the items. Three components had Eigenvalues exceeding 1.0, with the three-factor solution explaining $55.9 \%$ of the variance. The three components were labelled: support and opportunities to participate in research (Cronbach's alpha internal consistency 0.93 ); motivation for and outcomes of participation in research (Cronbach's alpha internal consistency 0.89); and individual roles and characteristics around participation in research (Cronbach's alpha internal consistency 0.87 ). Responses to items of these three components are given in Table 4.

$<$ Insert Table 4 here $>$

Component 1 - Support and opportunities to participate in research

Respondents generally held neutral views, with a median overall score of 47 (IQR 41 55), range possible 17-85 (midpoint 51), with 85 representing the highest possible positive score. The statement with the highest level of disagreement was 'I have sufficient time to participate in research' (disagree/strongly disagree $n=94,69.8 \%$ ). Other statements with more than $50 \%$ of respondents disagreeing were related to 
'working within a research active environment' $(n=63,50.8 \%)$, and being aware of research priorities of the organization $(n=63,50.8 \%)$, opportunities for research training ( $n=63,50.8 \%)$ and funding $(n=69,55.6 \%)$. Component 1 scores were statistically significantly higher for innovators/early adopters (Mann-Whitney $U, p<0.05$ ).

Component 2 - Motivation for and outcomes of participation in research

Responses were generally positive, with a median overall score of 28 (IQR 25-31), range possible 7-35 (midpoint 21), with 35 representing the highest possible positive score. While almost all felt that participating in research would be of benefit to their profession (agree/strongly agree $n=117,94.4 \%$ ) and patients (agree/strongly agree $n=112$, $90.4 \%$ ), less felt that there would be benefits to their own career (agree/strongly agree $\mathrm{n}=90,72.6 \%)$. Component 2 scores were statistically significantly higher for respondents who registered as pharmacists $<5$ years (Kruskal-Wallis, $p<0.05$ ).

Component 3 - Individual roles and characteristics around participation in research Respondents generally held positive views, with a median overall score of 35 (IQR 2939), range possible 10-50 (midpoint 30), with 50 representing the highest possible positive score. The most negative score was in relation to research participation already being part of their practise (disagree/strongly disagree $n=54,43.6 \%$ ). Component 3 scores were statistically significantly higher for those in secondary care (Kruskal-Wallis, $p<0.01$ ), with a postgraduate qualification (Mann-Whitney $U, p<0.001$ ) and innovators/early adopters (Mann-Whitney $U, p=0.001$ ).

Readiness to participate in research

In response to questions on involvement in research, $16.2 \%(n=22)$ had never thought about being involved in research, $19.1 \%(n=26)$ had thought about being involved but had taken no action, $10.3 \%(n=14)$ had thought about being involved and discussed with others, $17.6 \%(n=24)$ had been involved in research in the past but had no plans to be involved in the future, $14.7 \%(n=20)$ had been involved in research in the past and had plans to be involved in the future, and $12.5 \%(n=17)$ were currently involved in research. Those more ready were more likely to be $>35$ years $\left(x^{2}, p<0.05\right)$, working in secondary care $\left(X^{2}, p<0.001\right)$, pharmacists $>10$ years $\left(X^{2}, p<0.05\right)$, having a postgraduate qualification $\left(X^{2}, p<0.001\right)$ and being prescribers $\left(X^{2}, p=0.001\right)$.

In terms of research training, $28.7 \%(n=39)$ had never thought about research training, $27.9 \%(n=38)$ had thought about research training but had taken no action, $10.3 \%$ $(n=14)$ had thought about research training and discussed with others, $0.7 \%(n=1)$ had a plan for their research training, $1.5 \%(n=2)$ had enrolled for research training and $21.3 \%(n=29)$ had undertaken research training. Those more ready were more likely to 
be working in secondary care $\left(x^{2}, p=0.001\right)$, having a postgraduate qualification $\left(x^{2}\right.$, $p<0.05)$ and being prescribers $\left(x^{2}, p<0.05\right)$.

Almost three quarters of respondents $(70.7 \%, n=96)$ expressed interest in being involved in some form of research training; almost half $(41.9 \%, n=57)$ opted for training but not leading to a formal qualification, $14.8 \%(n=20)$ for university training at postgraduate level and $14.0 \%(n=19)$ for university training at doctorate level.

Application of research outcomes to practice

One hundred and twenty-four respondents completed all attitudinal items on the application of research outcomes (translation) to their practice. When these items were subjected to PCA, the correlation matrix contained multiple coefficients above 0.3 . The Kaiser-Meyer-Olkin measure of sampling adequacy (0.90) and Bartlett's test of sphericity $(p<0.001)$ confirmed the factorability of the items. Three components had eigenvalues exceeding 1.0, with the three-factor solution explained $61.4 \%$ of the variance. The three components were labelled: current practices and abilities to apply research outcomes (Cronbach's alpha internal consistency 0.91); consequences of applying research outcomes to practice (Cronbach's alpha internal consistency 0.90); and support to apply research outcomes to practice (Cronbach's alpha internal consistency 0.88 ). Responses to items of these three components are given in Table 5.

$<$ Insert table 5 here)

Component 1 - Current practices and abilities to apply research outcomes

Respondents generally held positive views, with a median overall score of 40 (IQR 3543.75), range possible 11-55 (midpoint 33 ), with 55 representing the highest possible positive score. The statements with the lowest levels of agreement were relating to supporting others to apply research outcomes (agree/strongly agree $n=58,46.8 \%$ ) and having clear goals to apply research outcomes $(n=46,37.1 \%)$. Component 1 scores were statistically significantly higher for respondents who were male (Mann-Whitney U, $p=0.025$ ), those in secondary care (Kruskal-Wallis, $p=0.001$ ), those with postgraduate qualifications (Mann-Whitney $U, p<0.001$ ), prescribers (Mann-Whitney $U, p<0.05$ ) and those innovators/early adopters (Mann-Whitney $U, p<0.001$ ).

Component 2 - Consequences of applying research outcomes to practice

Responses were generally very positive, with a median overall score of 24 (IQR 23-28), range possible 6-30 (midpoint 18 ), with 30 representing the highest possible positive score. The statement with the highest level of agreement was that applying research outcomes would be of benefit for patients (agree/strongly agree $n=116,93.6 \%$ ). Component 2 scores were statistically significantly higher for those in secondary care 
(Kruskal-Wallis, $p<0.05$ ), pharmacists for $11-20$ years (Kruskal-Wallis, $p<0.05$ ), and innovators/early adopters (Mann-Whitney $U, p<0.05$ ).

Component 3 - Support to apply research outcomes to practice

Respondents generally held positive attitudes, with a median overall score of 23 (IQR 20-26), range possible 7-35 (midpoint 21), with 35 representing the highest possible positive. The most negative score was in relation to having access to sufficient resources (strongly disagree/disagree $\mathrm{n}=88,71.0 \%$ ) and sufficient time (strongly disagree/disagree $n=77,62.1 \%$ ). Component 3 scores were statistically significantly higher for those working in secondary care (Kruskal-Wallis, $p<0.05$ ).

Content analysis of the textual responses to the open questions identified several key themes. While many expressed a desire to be more involved in research generally, lack of resources such as staffing, support and time were considered as key barriers,

"I would be more interested in becoming involved in research and appreciate its importance; however, chronic understaffing (due to maternity leave, sickness, failure to recruit etc.) means that it is a struggle to stay on top of the daily workload. All research would have to be done in own time, and this is a big commitment."

"I would love to be more involved in research in the fields I work in, I often think of ideas I would like to see explored but find it frustrating to find support and time to do so in existing role."

There was also an expressed need and desire to link academia and practice to better define research areas and questions considered more relevant hence more likely to inform and impact practice,

"I would like there to be more links between those in practice and research and bridge the gaps...lt seems a long time since any joint working like this has taken place."

"I think those in practice should get more opportunity to shape the direction of research as they are often more aware of the gaps and perhaps what is needed."

“...often we are asked to participate in research of little value to us and rarely hear back on the change the research has made to us/patient/organization/profession." 
While those involved in research in the past (e.g. MSc research project) acknowledged the benefits of publication, this appeared to rarely happen in practice,

"I completed my MSc research project, however did not have the time to publish.... also would have no idea how to go about publishing...jt is a skill that I struggle with."

“I have found it hard to get the momentum to keep anything we have started to be complete and often never get round to writing up or submitting for publication." 


\section{Discussion}

Statement of key findings

While respondents were generally interested in research, they were markedly less experienced or confident. PCA of items relating to views on research conduct/dissemination, and translation each identified three components. For research conduct/dissemination, the three components were: 'support and opportunities for participation'; 'motivation for and outcomes of participation'; and individual roles and characteristics around participation'. While scores for motivation and outcomes, and roles and characteristics were positive, those for support and opportunities were more negative. For translation, the three components were: 'current practices and abilities to apply research outcomes'; 'consequences of applying research outcomes'; and 'support to apply research outcomes'. Scores for all three components were positive, being most positive for consequences of applying research outcomes. Only one eighth of the respondents were currently involved in research. Those in secondary care, with a postgraduate qualification, prescribers and innovators/early adopters scored higher for interest, experience, confidence, readiness, and for most components.

Strengths and weaknesses

Key strengths of this research are the use of a framework of behavior change theories (TDF) in the development of selected questionnaire items, the focus on research conduct/dissemination and translation, and recruiting from all sectors of pharmacy practice. There are, however, several limitations hence the findings should be interpreted with caution. Despite all strategies to encourage participation, the response rate was low at around $20 \%$ which may have introduced response bias with non-respondents having no or little interest in research. The validity of self-reported data could not be confirmed and there may have been an elements of social desirability bias. Acquiescence bias may also have occurred surrounding the use of standard, fixed option responses for each item. Furthermore, responses are skewed with a higher proportion of those with postgraduate qualifications, prescribers and secondary care practice compared to the Scottish pharmacist population. The results may therefore lack generalisability within the study areas, Scotland and beyond. However, it is highly likely that the findings will resonate widely.

Interpretation of findings

Pharmacy practice models are developing at a pace globally, ${ }^{2}$ and particularly in Scotland with developments of government policy on the implementation of pharmacist independent prescribing, shared and integrated models of care and pharmacy 
practitioners practicing within primary care medical practices. ${ }^{22,31}$ Robust and rigorous research to demonstrate effectiveness, cost-effectiveness and safety is warranted and must be widely disseminated to achieve the greatest impact on professional practice, patient care, the economy and society. ${ }^{32}$ The argument can be made that pharmacy practice research should involve practicing pharmacists in all stages of research design, conduct and reporting. Furthermore, pharmacists should be reflecting on the findings of key research studies in relation to their practice and be considering adapting their practice accordingly.

The overall scores for research interest, experience and confidence were generally neutral, with those for interest being highest. These findings are not unique and have been identified in other pharmacist populations, ${ }^{8-18}$ and other health professions of medicine, nursing, social work and speech-language pathology. ${ }^{33-38}$ While responses to 'writing a research proposal' were particularly negative, this is not surprising given that not all pharmacists would be expected to be leading research teams or studies. Responses for 'writing and publishing in academic journals' were also negative, with particular issues around experience and confidence. Notably, few of the respondents had published any research in a peer-reviewed journal in the previous two years, a finding which was also apparent in the content analysis of textual responses. Given the need for dissemination of research to achieve the greatest impact, ${ }^{32}$ it is vital that research findings of all studies, including those with negative results, are published promptly following study completion.

In terms of the PCA of the items on research conduct/dissemination, component scores for 'support and opportunities to participate in research' were the lowest and generally neutral. This component included items on time for research, the environment, research priorities, opportunities, access to resources and individual goals for research. Interestingly, those respondents considering themselves innovators/early adopters scored higher. It may be that these individuals are more likely to set their own goals, seek opportunities, support and access. For 'motivation for and outcomes of participation in research', respondents were in agreement with the potential impact of research on patient care, professional practice and their career. In the last component, 'individual roles and characteristics around participation...' the item with the lowest score was around research being part of their practice. If research is not adequately resourced, then individuals may feel that it is not prioritised and can only be conducted either as part of a qualification or in their own time. This was highlighted in the content analysis of the responses to the open questions and also has been identified as a barrier by others. 8-18 
While several of these factors have been identified by others as key barriers to research participation none of these previous studies incorporated behavior change theory. Incorporating theory into research design, conduct and reporting is likely to generate findings which are much more comprehensive compared to studies which are conducted more pragmatically. Items within this component of 'support and opportunities to participate in research' can be mapped to TDF, enabling the identification of relevant behavior change interventions, 'coordinated sets of activities designed to change specified behavior patterns'. These consist of interacting components known as 'behavior change techniques' (BCTs), which are 'observable and replicable components designed to change behavior'. ${ }^{39}$ Evidence based BCTs have been mapped to specific TDF domains to facilitate intervention development. ${ }^{39,40}$ The lowest scoring items within this component map to TDF domains of knowledge (e.g. organization research priorities, training and funding opportunities), and 'environmental context and resources' (e.g. research active environment, time, support). While BCTs for knowledge are targeted at the individual, those relating to environmental context and resources relate more to organizational culture and will require intervention at the levels of the organization, leadership and management. ${ }^{41}$

Mapping the responses of research readiness to the Stage of Change model, ${ }^{25}$ almost one fifth of respondents were at the 'precontemplation' stage, never having thought about participation, and only one eighth currently participating, 'active'. For research training, the results were more marked with over a quarter being 'precontemplation'. Interestingly, those in secondary care, with a postgraduate qualification and being prescribers were more ready for research and research training. It may be that this setting is more conducive to research participation (e.g. access to resources, mentors etc.) and notably the scores for research interest, experience and confidence were also significantly higher for those who had completed postgraduate training.

PCA components of research translation were different to those for conduct/dissemination, with items clustering in 'current practices and abilities', 'consequences' and 'support'. Responses to all items were generally positive and thus component scores high, particularly those around consequences to patient care and professional practice. However, there were individuals scoring below the midpoint of each component hence may require further intervention to ensure that patients are receiving the most up-to-date, evidence based care. Given that component scores for all three components were significantly higher for those in secondary care, there may be merit in studying those in primary care settings in greater depth.

Many frameworks of research capacity building in healthcare have been published. One such framework has principles of: developing skills and confidence through training and 
opportunities to apply skills; supporting research 'close to practice'; need for partnership/collaboration; dissemination to maximise impact; continuity and sustainability; and appropriate infrastructures. ${ }^{42}$ This study has systematically studied pharmacists' aspirations, interests, experience, confidence, and views on research hence the findings can assist organizations to reflect on their strategic aims and plans and importantly ensure a positive research culture. Ideally this should be conducted within multidisciplinary teams and in partnership with academia.

While all pharmacists need to be research aware and translate research, fewer are likely to be involved in stages of conception, design, conduct and dissemination. The results of this study indicate that those in secondary care, with a postgraduate qualification, prescribers, and innovators/early adopters are more likely to be interested, experienced and confident, motivated with adequate support, more ready and should perhaps be targeted. However, the aspirations of the individual must also be considered in terms of their professional development. For those aspiring to be research leaders, frameworks which integrate academic and research pursuits integrated with clinical practice (i.e. 'clinical academics') may be suitable career pathway. While these are well-recognized within medicine and dentistry, and to a lesser extent, within nursing, they are less wellestablished for pharmacy. However, a recent paper from NHS Health Education England, has suggested a pathway for health professions outside of medicine and dentistry. ${ }^{43}$

Further work

Further research should focus on the development and testing of interventions around research capacity building (at individual and organizational levels) with outcome measures of process (e.g. research funding applications, research training events, research studies) and outcomes (e.g. conference presentations, publications) and impact (e.g. on patient care, professional practice).

\section{Conclusion}

Pharmacists are generally positive around the translation of research findings to practice, particularly around the consequences for patient care and professional practice. A minority of pharmacists are involved in the conduct and dissemination of research and these are more likely to be based in secondary care with a postgraduate qualification, being prescribers and innovators/early adopters. Given the need to develop, implement and evaluate new models of pharmaceutical care, involvement should be extended to all practice settings. This may require behaviour change interventions targeted at both the individuals and the organizations. 


\section{Funding sources}

This research was funded by Robert Gordon University

\section{Acknowledgements}

The authors wish to acknowledge all pharmacists who completed the questionnaire.

\section{References}

1. Dawes M, Summerskill W, Glasziou P, Cartabellotta A, Martin J, Hopayian K, Porzsolt F, Burls A, Osborne J. Sicily statement on evidence-based practice. BMC Med Educ 2005; $5: 1$.

2. International Pharmaceutical Federation. Available at: https://www. fip.org/ [cited August 2018].

3. European Society of Clinical Pharmacy. Available at: https://www.escpweb.org/ [cited August 2018].

4. European Association of Hospital Pharmacists. Available at: http://www.eahp.eu/ [cited August 2018].

5. American Society of Health-System Pharmacists. Available at: https://www.ashp.org/ [cited August 2018].

6. Royal Pharmaceutical Society. Available at: https://www.rpharms.com/ [cited August 2018].

7. Department for International Development. Capacity building in research. Available at:

https://www.gov.uk/government/uploads/system/uploads/attachment_data/file/187568/ HTN_Capacity_Building_Final_21_06_10.pdf [cited August 2018]

8. Awaisu A, Alsalimy N. Pharmacists' involvement in and attitudes toward pharmacy practice research: A systematic review of the literature. Res Social Adm Pharm 2015; 11: 725-48.

9. Lowrie R, Morrison G, Lees R, Grant CH, Johnson C, MacLean F, Semple Y, Thomson A, Harrison $H$, Mullen AB, Lannigan N. Research is 'a step into the unknown': an exploration of pharmacists' perceptions of factors impacting on research participation in the NHS. BMJ open 2015; 5:e009180.

10. Stewart D, Al Hail M, Rouf PA, El Kassem W, Diack L, Thomas B, Awaisu A. Building hospital pharmacy practice research capacity in Qatar: a cross-sectional survey of hospital pharmacists. Int J Clin Pharm 2015;37:511-21.

11. Sultana K, Al J eraisy M, Al Ammari M, Patel R, Zaidi ST. Attitude, barriers and facilitators to practice-based research: cross-sectional survey of hospital pharmacists in Saudi Arabia. J Pharm Policy Pract 2016; 9:4.

12. Bhagavathula AS, Gebreyohannes EA, Gebresillassie BM, Erku DA, Negesse CT, Belay

YB. Community pharmacists' interest in and attitude to pharmacy practice research in Ethiopia: A cross-sectional study. PloS One 2017; 12: e0178919. 
13. Bulkley CF, Miller MJ, Bush CG, Nussbaum BB, Draugalis JR. Needs assessment for developing a program to help train advanced-practice pharmacists for research. Am J Health Syst Pharm 2017; 74: 1986-95.

14. Crilly P, Patel N, Ogunrinde A, Berko D, Kayyali R. Community Pharmacists' Involvement in Research in the United Kingdom. Pharmacy 2017; 5:48.

15. Fakeye TO, Adisa R, Olukotun RT, Morawo PK. Hospital and community pharmacists' perception of the scope, barriers and challenges of pharmacy practice-based research in Nigeria. Pharm Pract 2017;15(1).

16. Lee R, Dahri K, Lau TT, Shalansky S. Perceptions of hospital pharmacists concerning clinical research: a survey study. Can J Hosp Pharm 2018; 71.

17. Abubakar U, Sulaiman SA, Usman MN, Umar MD. Nigerian pharmacists' selfperceived competence and confidence to plan and conduct pharmacy practice research. Pharm Pract 2018; 16.

18. Tan SY, Hatah E. Knowledge, attitudes, practices, and barriers related to research utilization: a survey among pharmacists in Malaysia. Int J Clin Pharm 2017; 39:450-8.

19. Stewart D, Klein S. The use of theory in research. Int J Clin Pharm 2016; 38:615-9.

20. Cane J, O'Connor D, Michie S. Validation of the theoretical domains framework for use in behaviour change and implementation research. Implement Sci 2012; 7:37.

21. Craig P, Dieppe P, Macintyre S, Michie S, Nazareth I, Petticrew M. Developing and evaluating complex interventions: the new Medical Research Council guidance. Brit Med J 2008; 337:a1665.

22. Scottish Government. Achieving Excellence in Pharmaceutical Care: A Strategy for Scotland. Edinburgh: The Scottish Government; 2017. Available at: http://www.gov.scot/Resource/0052/00523589.pdf [cited August 2018].

23. Michie S, Johnson M, Abraham C, Lawton R, Parker D, Walker A, on behalf of the 'Psychological Theory' Group. Making psychological theory useful for implementing evidence based practice: a consensus approach. Qual Saf Health Care 2005; 14:26-33.

24. Huijg J M, Gebhardt WA, Dusseldorp E, Verheijden MW, van der Zouwe N, Middelkoop BJ , Crone MR. Measuring determinants of implementation behavior: psychometric properties of a questionnaire based on the theoretical domains framework. Implement Sci 2014; 9:33.

25. Prochaska J O, Velicer WF. The transtheoretical model of health behavior change. Am J Health Promot 1997; 2: 38.

26. Rogers EM. Diffusion of Innovations. New York, NY: Free Press; 2003. ISBN 9780743222099

27. Nakash RA, Hutton J L, Jorstad Stein, Gates S, Lamb SE. Maximising response to questionnaires - A systematic review of randomised trials in health research. BMC Med Res Methodol 2006; 6:5.

28. DeVellis, R.F., 1991. Scale development: theory and applications. California: Sage Publications. ISBN 9781412980449.

29. Pallant, J. SPSS survival manual. United Kingdom: McGraw-Hill Education, 2013. 
30. Elo, S., Kääriäinen, M., Kanste, O., Pölkki, T., Utriainen, K., Kyngäs, H. Qualitative content analysis: a focus on trustworthiness. Sage Open 2014:1-10.

31. Scottish Government. Prescription for Excellence. Edinburgh: The Scottish Government; 2013. Available at: http://www.gov.scot/resource/0043/00434053. pdf [cited August 2018].

32. Milat AJ, Bauman AE, Redman S. A narrative review of research impact assessment models and methods. Health Res Policy Sys 2015;13:18.

33. Berger R. EBP: practitioners in search of evidence. J Soc Work 2010; 10: 175.

34. Harvey D, Plummer D, Pighills A, Pain T. Practitioner research capacity: A survey of social workers in Northern Queensland. Aus Soc Work 2013;66:540-54.

35. Pager S, Holden L, Golenko X. Motivators, enablers, and barriers to building allied health research capacity. J Multidiscip Health 2012;5:53-9.

36. Finch E, Cornwell P, Ward EC, McPhail SM. Factors influencing research engagement: research interest, confidence and experience in an Australian speech-language pathology workforce. BMC Health Serv Res 2013; 13: 144.

37. Salmon P, Peters S, Rogers A, Gask L, Clifford R, I redale W, Morriss R. Peering through the barriers in GPs' explanations for declining to participate in research: the role of professional autonomy and the economy of time. Fam Pract 2007;24:269.

38. McMaster R, Jammali-Blasi A, Andersson-Noorgard K, Cooper K, Mclnnes E. Research involvement, support needs, and factors affecting research participation: A survey of Mental Health Consultation Liaison Nurses. Int J Ment Health Nurs 2013;22: 154-161.

39. Michie S, Richardson M, Johnston M, Abraham C, Francis J, Hardeman W, et al. The behavior change technique taxonomy ( $v 1$ ) of 93 hierarchically clustered techniques: building an international consensus for the reporting of behavior change interventions. Ann Behav Med 2013; 46:81-95.

40. Michie S, Wood CE, J ohnston M, Abraham C, Francis J, Hardeman W, et al. Behaviour change techniques: the development and evaluation of a taxonomic method for reporting and describing behaviour change interventions (a suite of five studies involving consensus methods, randomised controlled trials and analysis of qualitative data). Health Technol Assess 2015; 19.

41. Alvesson M, Sveningsson S. Changing organizational culture: Cultural change work in progress. England: Routledge; 2015.

42. Cooke J. A framework to evaluate research capacity building in health care. BMC Fam Pract 2005; 6: 44.

43. NHS Health Education England. Clinical Academic Careers Framework: A framework for optimising clinical academic careers across healthcare professions. Available at: https:// hee.nhs.uk/sites/default/files/documents/2018-02\% 20CAC\% 20Framework.pdf [cited August 2018]. 


\section{Tables}

Table 1. Policy and practice statements, with emphasis on practice research, of key pharmacy organizations

\begin{tabular}{|c|c|}
\hline Organization & Statements \\
\hline $\begin{array}{l}\text { International } \\
\text { Pharmaceutical } \\
\text { Federation (FIP) }\end{array}$ & $\begin{array}{l}\text { Vision } \\
\text { Wherever and whenever decision-makers discuss any aspects } \\
\text { of medicines on a global level, FIP is at the table. } \\
\text { Mission } \\
\text { Improve global health by advancing pharmaceutical education, } \\
\text { pharmaceutical sciences and pharmaceutical practice thus } \\
\text { encouraging, promoting and enabling better discovery, } \\
\text { development, access to and responsible use of appropriate, } \\
\text { cost-effective, quality medicines worldwide. } \\
\\
\text {..such a vision involves and evokes a wide range of responses } \\
\text { and commitments:...identifying and taking on significant } \\
\text { responsibilities in pharmacy practice research }\end{array}$ \\
\hline $\begin{array}{l}\text { European Society of } \\
\text { Clinical Pharmacy } \\
(\text { ESCP) })^{3}\end{array}$ & $\begin{array}{l}\text { Vision } \\
\text { ESCP is an international leader in advancing quality and } \\
\text { innovation in clinical pharmacy education, practice and } \\
\text { research. } \\
\text { Mission } \\
\text { ESCP is an organization that promotes, supports, implements } \\
\text { and advances education, practice and research in clinical } \\
\text { pharmacy in order to optimise outcomes for patients and } \\
\text { society. } \\
\text { ESCP advances research by: } \\
\text { 1. Disseminating clinical pharmacy research findings } \\
\text { 2. Stimulating innovative and high quality research in all areas } \\
\text { of clinical pharmacy } \\
\text { 3. Promoting and enabling multicentre research in all areas of } \\
\text { clinical pharmacy both within countries and between countries } \\
\text { or differing healthcare delivery systems }\end{array}$ \\
\hline $\begin{array}{l}\text { European } \\
\text { Association of } \\
\text { Hospital Pharmacists } \\
(\text { EAHP) }\end{array}$ & $\begin{array}{l}\text { Mission } \\
\text { EAHP represents and develops the hospital pharmacy } \\
\text { profession within Europe in order to ensure the continuous } \\
\text { improvement of care and outcomes for patients in the hospital } \\
\text { setting. This is achieved through science, research, education, } \\
\text { practice, as well as sharing best-practice and responsibility } \\
\text { with other healthcare professionals. } \\
\text { European Statements of Hospital Pharmacy } \\
\text { Section 6: Education and Research } \\
\text { Statement } 6.4 \text {. Hospital pharmacists should actively engage in } \\
\text { and publish research, particularly on hospital pharmacy } \\
\text { practice. Research methods should be part of undergraduate } \\
\text { and postgraduate training programmes for hospital } \\
\text { pharmacists. Hospital pharmacists should be actively involved } \\
\text { in clinical trials of medicines. }\end{array}$ \\
\hline
\end{tabular}




\begin{tabular}{|c|c|}
\hline $\begin{array}{l}\text { American Society of } \\
\text { Health-System } \\
\text { Pharmacists (ASHP) } 5\end{array}$ & $\begin{array}{l}\text { Vision } \\
\text { Patient outcomes improve because of the leadership and } \\
\text { clinical skills of pharmacists, as vital members of the } \\
\text { healthcare team, accountable for safe and effective medication } \\
\text { use. } \\
\text { Mission } \\
\text {..to improve the health and well-being of patients through } \\
\text { appropriate, safe and effective medication use. } \\
\text { (Relating to research) We will accomplish this by: } \\
\text { - sponsoring high-impact practice research leading to advances } \\
\text { in patient outcomes } \\
\text { - providing funding and programs that optimize the } \\
\text { medication-use system and advance the direct and accountable } \\
\text { patient care role of pharmacists } \\
\text { - encouraging innovation and adoption of best practices and } \\
\text { new patient safety and quality initiatives } \\
\text { - providing recognition and support to diffuse best practices in } \\
\text { research, education and practice }\end{array}$ \\
\hline $\begin{array}{l}\text { Royal } \\
\text { Pharmaceutical } \\
\text { Society (RPS) }\end{array}$ & $\begin{array}{l}\text { Mission } \\
\text { To promote and represent the professional } \\
\text { interests of our members, supporting the profession to achieve } \\
\text { our shared vision for the future. We are committed to } \\
\text { supporting and empowering our members to make a real } \\
\text { difference to improving health outcomes for patients. } \\
\text { Professional Standards for Hospital Pharmacy Services } \\
\text { Standard } 6.4 d \text {. The pharmacy team leads, actively participates } \\
\text { in and publishes research... and seeks opportunities to work } \\
\text { with academia and other research partners }\end{array}$ \\
\hline
\end{tabular}


Table 2. Personal and practice demographics of respondents $(n=136)$

\begin{tabular}{|c|c|}
\hline Demographic & $\%(n)$ \\
\hline $\begin{array}{l}\text { Age (years) } \\
\quad \leq 35 \\
36-45 \\
>45 \\
\text { missing }\end{array}$ & $\begin{array}{l}35.3(48) \\
30.9(42) \\
30.9(42) \\
2.9(4) \\
\end{array}$ \\
\hline $\begin{array}{l}\text { Gender } \\
\text { Female } \\
\text { Male } \\
\end{array}$ & $\begin{array}{l}76.5(104) \\
23.5(32)\end{array}$ \\
\hline $\begin{array}{l}\text { Main practice setting } \\
\text { Primary care } \\
\text { Secondary care } \\
\text { Community pharmacy } \\
\text { Other }\end{array}$ & $\begin{array}{l}25.0(34) \\
41.2(56) \\
25.7(35) \\
8.1(11)\end{array}$ \\
\hline $\begin{array}{l}\text { Years of practise as pharmacist } \\
\leq 10 \\
11-20 \\
>20\end{array}$ & $\begin{array}{l}30.1(41) \\
34.6(47) \\
35.3(48) \\
\end{array}$ \\
\hline $\begin{array}{l}\text { Working schedule } \\
\text { Full time } \\
\text { Part time } \\
\text { As a locum } \\
\text { Other } \\
\end{array}$ & $\begin{array}{l}67.6(92) \\
28.7(39) \\
2.2(3) \\
1.5(2)\end{array}$ \\
\hline $\begin{array}{l}\text { Postgraduate qualifications } \\
\text { Yes }\end{array}$ & $58.1(79)$ \\
\hline $\begin{array}{l}\text { Pharmacist prescriber } \\
\text { Yes }\end{array}$ & $50.7(69)$ \\
\hline $\begin{array}{l}\text { Receptivity to change } \\
\text { Innovative with new ways of working (innovator) } \\
\text { Serve as a role model for others in relation to new ways of working (early } \\
\text { adopter) } \\
\text { Think for some time before adopting new ways of working (early majority) } \\
\text { Cautious in relation to new ways of working; tend to change once most } \\
\text { peers have done so (late majority) } \\
\text { Resist new ways of working (laggard) }\end{array}$ & $\begin{array}{l}35.3(48) \\
23.5(32) \\
38.2(52) \\
2.9(4) \\
0(0)\end{array}$ \\
\hline
\end{tabular}


Table 3. Responses to items of interest, experience and confidence in specific aspects of research $(n=136)$

\begin{tabular}{|c|c|c|c|c|c|c|c|c|c|c|c|c|c|c|c|}
\hline \multirow[b]{2}{*}{ I tem } & \multicolumn{5}{|c|}{ I nterest \% (n) } & \multicolumn{5}{|c|}{ Experience \% (n) } & \multicolumn{5}{|c|}{ Confidence \% (n) } \\
\hline & 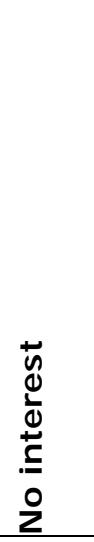 & 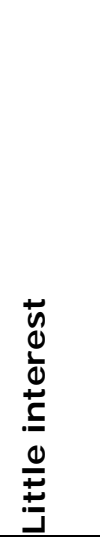 & 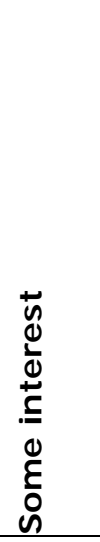 & 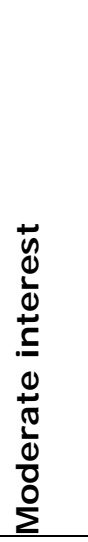 & 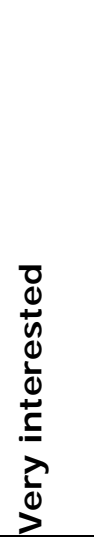 & 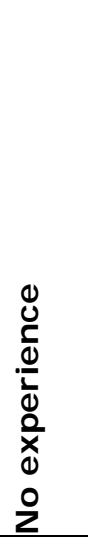 & 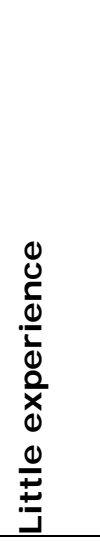 & 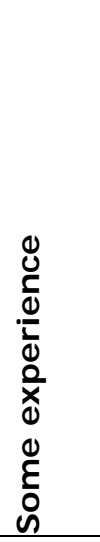 & 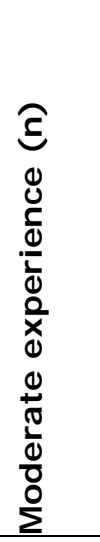 & 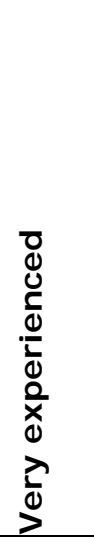 & $\begin{array}{l}0 \\
0 \\
0 \\
0 \\
0 \\
\frac{0}{4} \\
0 \\
0 \\
0 \\
z\end{array}$ & 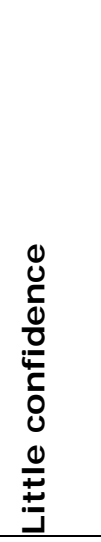 & 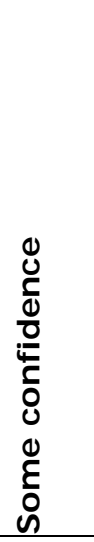 & 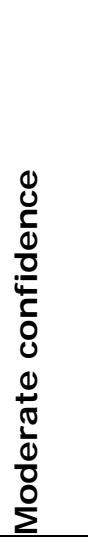 & 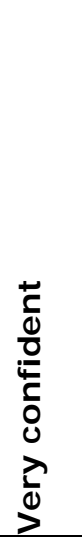 \\
\hline $\begin{array}{l}\text { Research advances } \\
\text { within my field and } \\
\text { in related areas }\end{array}$ & $\begin{array}{l}0.7 \\
(1)\end{array}$ & $\begin{array}{l}5.1 \\
(7)\end{array}$ & $\begin{array}{l}19.1 \\
(26)\end{array}$ & $\begin{array}{l}30.9 \\
(42)\end{array}$ & $\begin{array}{l}44.1 \\
(60)\end{array}$ & $\begin{array}{l}24.3 \\
(33)\end{array}$ & $\begin{array}{l}25.7 \\
(35)\end{array}$ & $\begin{array}{l}28.7 \\
(39)\end{array}$ & $\begin{array}{l}16.2 \\
(22)\end{array}$ & $\begin{array}{l}5.1 \\
(7)\end{array}$ & $\begin{array}{l}17.6 \\
(24)\end{array}$ & $\begin{array}{l}22.8 \\
(31)\end{array}$ & $\begin{array}{l}25.7 \\
(35)\end{array}$ & $\begin{array}{l}30.1 \\
(41)\end{array}$ & $\begin{array}{l}3.7 \\
(5)\end{array}$ \\
\hline $\begin{array}{l}\text { Generating research } \\
\text { ideas }\end{array}$ & $\begin{array}{l}4.4 \\
(6)\end{array}$ & $\begin{array}{l}22.8 \\
(31)\end{array}$ & $\begin{array}{l}29.4 \\
(40)\end{array}$ & $\begin{array}{l}26.5 \\
(36)\end{array}$ & $\begin{array}{l}16.9 \\
(23)\end{array}$ & $\begin{array}{l}27.9 \\
(38)\end{array}$ & $\begin{array}{l}35.3 \\
(48)\end{array}$ & $\begin{array}{l}26.5 \\
(36)\end{array}$ & $\begin{array}{l}7.4 \\
(10)\end{array}$ & $\begin{array}{l}2.9 \\
(4)\end{array}$ & $\begin{array}{l}23.5 \\
(32)\end{array}$ & $\begin{array}{l}28.7 \\
(39)\end{array}$ & $\begin{array}{l}29.4 \\
(40)\end{array}$ & $\begin{array}{l}16.2 \\
(22)\end{array}$ & $\begin{array}{l}2.2 \\
(3)\end{array}$ \\
\hline $\begin{array}{l}\text { Developing research } \\
\text { questions, aims, } \\
\text { hypotheses and } \\
\text { objectives }\end{array}$ & $\begin{array}{l}8.8 \\
(12)\end{array}$ & $\begin{array}{l}30.1 \\
(41)\end{array}$ & $\begin{array}{l}28.7 \\
(39)\end{array}$ & $\begin{array}{l}19.1 \\
(26)\end{array}$ & $\begin{array}{l}13.2 \\
(18)\end{array}$ & $\begin{array}{l}25.7 \\
(35)\end{array}$ & $\begin{array}{l}39.7 \\
(54)\end{array}$ & $\begin{array}{l}23.5 \\
(32)\end{array}$ & $\begin{array}{l}8.8 \\
(12)\end{array}$ & $\begin{array}{l}2.2 \\
(3)\end{array}$ & $\begin{array}{l}24.3 \\
(33)\end{array}$ & $\begin{array}{l}33.8 \\
(46)\end{array}$ & $\begin{array}{l}25.0 \\
(34)\end{array}$ & $\begin{array}{l}14.7 \\
(20)\end{array}$ & $\begin{array}{l}2.2 \\
(3)\end{array}$ \\
\hline $\begin{array}{l}\text { Finding relevant } \\
\text { literature }\end{array}$ & $\begin{array}{l}6.6 \\
(9)\end{array}$ & $\begin{array}{l}16.9 \\
(23)\end{array}$ & $\begin{array}{l}26.5 \\
(36)\end{array}$ & $\begin{array}{l}29.4 \\
(40)\end{array}$ & $\begin{array}{l}20.6 \\
(28)\end{array}$ & $\begin{array}{l}16.9 \\
(23)\end{array}$ & $\begin{array}{l}18.4 \\
(25)\end{array}$ & $\begin{array}{l}32.4 \\
(44)\end{array}$ & $\begin{array}{l}23.5 \\
(32)\end{array}$ & $\begin{array}{l}8.8 \\
(12)\end{array}$ & $\begin{array}{l}14.0 \\
(19)\end{array}$ & $\begin{array}{l}16.9 \\
(23)\end{array}$ & $\begin{array}{l}31.6 \\
(43)\end{array}$ & $\begin{array}{l}27.2 \\
(37)\end{array}$ & $\begin{array}{l}10.3 \\
(14)\end{array}$ \\
\hline
\end{tabular}




\begin{tabular}{|c|c|c|c|c|c|c|c|c|c|c|c|c|c|c|c|}
\hline Reviewing literature & $\begin{array}{l}7.4 \\
(10)\end{array}$ & $\begin{array}{l}19.1 \\
(26)\end{array}$ & $\begin{array}{l}29.4 \\
(40)\end{array}$ & $\begin{array}{l}26.5 \\
(36)\end{array}$ & $\begin{array}{l}17.6 \\
(24)\end{array}$ & $\begin{array}{l}17.6 \\
(24)\end{array}$ & $\begin{array}{l}19.9 \\
(27)\end{array}$ & $\begin{array}{l}29.4 \\
(40)\end{array}$ & $\begin{array}{l}22.8 \\
(31)\end{array}$ & $\begin{array}{l}10.3 \\
(14)\end{array}$ & $\begin{array}{l}13.2 \\
(18)\end{array}$ & $\begin{array}{l}20.6 \\
(28)\end{array}$ & $\begin{array}{l}30.1 \\
(41)\end{array}$ & $\begin{array}{l}27.2 \\
(37)\end{array}$ & $\begin{array}{l}8.8 \\
(12)\end{array}$ \\
\hline $\begin{array}{l}\text { Writing a research } \\
\text { proposal }\end{array}$ & $\begin{array}{l}14.7 \\
(20)\end{array}$ & $\begin{array}{l}36.8 \\
(50)\end{array}$ & $\begin{array}{l}27.2 \\
(37)\end{array}$ & $\begin{array}{l}13.2 \\
(18)\end{array}$ & $\begin{array}{l}8.1 \\
(11)\end{array}$ & $\begin{array}{l}34.6 \\
(47)\end{array}$ & $\begin{array}{l}31.6 \\
(43)\end{array}$ & $\begin{array}{l}22.8 \\
(31)\end{array}$ & $\begin{array}{l}8.8 \\
(12)\end{array}$ & $\begin{array}{l}2.2 \\
(3)\end{array}$ & $\begin{array}{l}30.1 \\
(41)\end{array}$ & $\begin{array}{l}32.4 \\
(44)\end{array}$ & $\begin{array}{l}23.5 \\
(32)\end{array}$ & $\begin{array}{l}11.8 \\
(16)\end{array}$ & $\begin{array}{l}2.2 \\
(3)\end{array}$ \\
\hline $\begin{array}{l}\text { Conducting a } \\
\text { systematic review }\end{array}$ & $\begin{array}{l}14.0 \\
(19)\end{array}$ & $\begin{array}{l}35.3 \\
(48)\end{array}$ & $\begin{array}{l}27.2 \\
(37)\end{array}$ & $\begin{array}{l}14.7 \\
(20)\end{array}$ & $\begin{array}{l}8.8 \\
(12)\end{array}$ & $\begin{array}{l}39.0 \\
(53)\end{array}$ & $\begin{array}{l}30.1 \\
(41)\end{array}$ & $\begin{array}{l}19.9 \\
(27)\end{array}$ & $\begin{array}{l}8.1 \\
(11)\end{array}$ & $\begin{array}{l}2.9 \\
(4)\end{array}$ & $\begin{array}{l}33.8 \\
(46)\end{array}$ & $\begin{array}{l}32.4 \\
(44)\end{array}$ & $\begin{array}{l}17.6 \\
(24)\end{array}$ & $\begin{array}{l}13.2 \\
(18)\end{array}$ & $\begin{array}{l}2.9 \\
(4)\end{array}$ \\
\hline $\begin{array}{l}\text { Using quantitative } \\
\text { research methods } \\
\text { (e.g. RCTs, cohort } \\
\text { studies, surveys, } \\
\text { questionnaires) }\end{array}$ & $\begin{array}{l}10.3 \\
(14)\end{array}$ & $\begin{array}{l}22.1 \\
(30)\end{array}$ & $\begin{array}{l}36.0 \\
(49)\end{array}$ & $\begin{array}{l}16.9 \\
(23)\end{array}$ & $\begin{array}{l}14.7 \\
(20)\end{array}$ & $\begin{array}{l}30.1 \\
(41)\end{array}$ & $\begin{array}{l}33.8 \\
(46)\end{array}$ & $\begin{array}{l}25.0 \\
(34)\end{array}$ & $\begin{array}{l}7.4 \\
(10)\end{array}$ & $\begin{array}{l}3.7 \\
(5)\end{array}$ & $\begin{array}{l}23.5 \\
(32)\end{array}$ & $\begin{array}{l}27.2 \\
(37)\end{array}$ & $\begin{array}{l}32.4 \\
(44)\end{array}$ & $\begin{array}{l}14.0 \\
(19)\end{array}$ & $\begin{array}{l}2.9 \\
(4)\end{array}$ \\
\hline $\begin{array}{l}\text { Using qualitative } \\
\text { research methods } \\
\text { (e.g. focus groups, } \\
\text { interviews) }\end{array}$ & $\begin{array}{l}8.8 \\
(12)\end{array}$ & $\begin{array}{l}25.0 \\
(34)\end{array}$ & $\begin{array}{l}33.8 \\
(46)\end{array}$ & $\begin{array}{l}22.8 \\
(31)\end{array}$ & $\begin{array}{l}9.6 \\
(13)\end{array}$ & $\begin{array}{l}36.0 \\
(49)\end{array}$ & $\begin{array}{l}32.4 \\
(44)\end{array}$ & $\begin{array}{l}19.1 \\
(26)\end{array}$ & $\begin{array}{l}8.8 \\
(12)\end{array}$ & $\begin{array}{l}3.7 \\
(5)\end{array}$ & $\begin{array}{l}24.3 \\
(33)\end{array}$ & $\begin{array}{l}35.3 \\
(48)\end{array}$ & $\begin{array}{l}25.0 \\
(34)\end{array}$ & $\begin{array}{l}12.5 \\
(17)\end{array}$ & $\begin{array}{l}2.9 \\
(4)\end{array}$ \\
\hline $\begin{array}{l}\text { Analysing and } \\
\text { interpreting } \\
\text { quantitative results }\end{array}$ & $\begin{array}{l}8.8 \\
(12)\end{array}$ & $\begin{array}{l}25.0 \\
(34)\end{array}$ & $\begin{array}{l}28.7 \\
(39)\end{array}$ & $\begin{array}{l}22.8 \\
(31)\end{array}$ & $\begin{array}{l}14.7 \\
(20)\end{array}$ & $\begin{array}{l}24.3 \\
(33)\end{array}$ & $\begin{array}{l}27.9 \\
(38)\end{array}$ & $\begin{array}{l}30.9 \\
(42)\end{array}$ & $\begin{array}{l}14.0 \\
(19)\end{array}$ & $\begin{array}{l}2.9 \\
(4)\end{array}$ & $\begin{array}{l}16.9 \\
(23)\end{array}$ & $\begin{array}{l}33.8 \\
(46)\end{array}$ & $\begin{array}{l}27.2 \\
(37)\end{array}$ & $\begin{array}{l}19.1 \\
(26)\end{array}$ & $\begin{array}{l}2.9 \\
(4)\end{array}$ \\
\hline $\begin{array}{l}\text { Analysing and } \\
\text { interpreting } \\
\text { qualitative results }\end{array}$ & $\begin{array}{l}9.6 \\
(13)\end{array}$ & $\begin{array}{l}23.5 \\
(32)\end{array}$ & $\begin{array}{l}33.1 \\
(45)\end{array}$ & $\begin{array}{l}22.1 \\
(30)\end{array}$ & $\begin{array}{l}11.8 \\
(16)\end{array}$ & $\begin{array}{l}29.4 \\
(40)\end{array}$ & $\begin{array}{l}31.6 \\
(43)\end{array}$ & $\begin{array}{l}25.0 \\
(34)\end{array}$ & $\begin{array}{l}11.8 \\
(16)\end{array}$ & $\begin{array}{l}2.2 \\
(3)\end{array}$ & $\begin{array}{l}21.3 \\
(29)\end{array}$ & $\begin{array}{l}36.0 \\
(49)\end{array}$ & $\begin{array}{l}24.3 \\
(33)\end{array}$ & $\begin{array}{l}15.4 \\
(21)\end{array}$ & $\begin{array}{l}2.9 \\
(4)\end{array}$ \\
\hline $\begin{array}{l}\text { Giving an oral } \\
\text { presentation locally }\end{array}$ & $\begin{array}{l}9.6 \\
(13)\end{array}$ & $\begin{array}{l}19.1 \\
(26)\end{array}$ & $\begin{array}{l}25.7 \\
(35)\end{array}$ & $\begin{array}{l}27.9 \\
(38)\end{array}$ & $\begin{array}{l}17.6 \\
(24)\end{array}$ & $\begin{array}{l}16.2 \\
(22)\end{array}$ & $\begin{array}{l}18.4 \\
(25)\end{array}$ & $\begin{array}{l}22.1 \\
(30)\end{array}$ & $\begin{array}{l}29.4 \\
(40)\end{array}$ & $\begin{array}{l}14.0 \\
(19)\end{array}$ & $\begin{array}{l}10.3 \\
(14)\end{array}$ & $\begin{array}{l}16.2 \\
(22)\end{array}$ & $\begin{array}{l}29.4 \\
(40)\end{array}$ & $\begin{array}{l}29.4 \\
(40)\end{array}$ & $\begin{array}{l}14.7 \\
(20)\end{array}$ \\
\hline
\end{tabular}




\begin{tabular}{|c|c|c|c|c|c|c|c|c|c|c|c|c|c|c|c|}
\hline $\begin{array}{l}\text { Giving an oral } \\
\text { presentation at } \\
\text { national or } \\
\text { international } \\
\text { conference }\end{array}$ & $\begin{array}{l}14.7 \\
(20)\end{array}$ & $\begin{array}{l}20.6 \\
(28)\end{array}$ & $\begin{array}{l}25.7 \\
(35)\end{array}$ & $\begin{array}{l}24.3 \\
(33)\end{array}$ & $\begin{array}{l}14.7 \\
(20)\end{array}$ & $\begin{array}{l}50.7 \\
(69)\end{array}$ & $\begin{array}{l}18.4 \\
(25)\end{array}$ & $\begin{array}{l}17.6 \\
(24)\end{array}$ & $\begin{array}{l}10.3 \\
(14)\end{array}$ & $\begin{array}{l}2.9 \\
(4)\end{array}$ & $\begin{array}{l}23.5 \\
(32)\end{array}$ & $\begin{array}{l}27.2 \\
(37)\end{array}$ & $\begin{array}{l}23.5 \\
(32)\end{array}$ & $\begin{array}{l}20.6 \\
(28)\end{array}$ & $\begin{array}{l}5.1 \\
(7)\end{array}$ \\
\hline $\begin{array}{l}\text { Writing and } \\
\text { publishing research } \\
\text { in academic journals }\end{array}$ & $\begin{array}{l}14.0 \\
(19)\end{array}$ & $\begin{array}{l}28.7 \\
(39)\end{array}$ & $\begin{array}{l}26.5 \\
(36)\end{array}$ & $\begin{array}{l}14.0 \\
(19)\end{array}$ & $\begin{array}{l}16.9 \\
(23)\end{array}$ & $\begin{array}{l}59.6 \\
(81)\end{array}$ & $\begin{array}{l}19.9 \\
(27)\end{array}$ & $\begin{array}{l}15.4 \\
(21)\end{array}$ & $\begin{array}{l}2.9 \\
(4)\end{array}$ & $\begin{array}{l}2.2 \\
(3)\end{array}$ & $\begin{array}{l}34.6 \\
(47)\end{array}$ & $\begin{array}{l}37.5 \\
(51)\end{array}$ & $\begin{array}{l}15.4 \\
(21)\end{array}$ & $\begin{array}{l}10.3 \\
(14)\end{array}$ & $\begin{array}{l}2.2 \\
(3)\end{array}$ \\
\hline $\begin{array}{l}\text { Reading and } \\
\text { interpreting research }\end{array}$ & $\begin{array}{l}8.8 \\
(12)\end{array}$ & $\begin{array}{l}17.6 \\
(24)\end{array}$ & $\begin{array}{l}27.2 \\
(37)\end{array}$ & $\begin{array}{l}25.0 \\
(34)\end{array}$ & $\begin{array}{l}21.3 \\
(29)\end{array}$ & $\begin{array}{l}22.8 \\
(31)\end{array}$ & $\begin{array}{l}21.3 \\
(29)\end{array}$ & $\begin{array}{l}24.3 \\
(33)\end{array}$ & $\begin{array}{l}20.6 \\
(28)\end{array}$ & $\begin{array}{l}11.0 \\
(15)\end{array}$ & $\begin{array}{l}14.7 \\
(20)\end{array}$ & $\begin{array}{l}22.1 \\
(30)\end{array}$ & $\begin{array}{l}27.2 \\
(37)\end{array}$ & $\begin{array}{l}30.1 \\
(41)\end{array}$ & $\begin{array}{l}5.9 \\
(8)\end{array}$ \\
\hline $\begin{array}{l}\text { Applying the } \\
\text { outcomes of } \\
\text { research to your } \\
\text { practice }\end{array}$ & $\begin{array}{l}3.7 \\
(5)\end{array}$ & $\begin{array}{l}5.9 \\
(8)\end{array}$ & $\begin{array}{l}18.4 \\
(25)\end{array}$ & $\begin{array}{l}28.7 \\
(39)\end{array}$ & $\begin{array}{l}43.4 \\
(59)\end{array}$ & $\begin{array}{l}17.6 \\
(24)\end{array}$ & $\begin{array}{l}14.0 \\
(19)\end{array}$ & $\begin{array}{l}34.6 \\
(47)\end{array}$ & $\begin{array}{l}22.1 \\
(30)\end{array}$ & $\begin{array}{l}11.8 \\
(16)\end{array}$ & $\begin{array}{l}13.2 \\
(18)\end{array}$ & $\begin{array}{l}14.0 \\
(19)\end{array}$ & $\begin{array}{l}28.7 \\
(39)\end{array}$ & $\begin{array}{l}35.3 \\
(48)\end{array}$ & $\begin{array}{l}8.8 \\
(12)\end{array}$ \\
\hline $\begin{array}{l}\text { Scale statistics, sum } \\
\text { of allocating } 1 \text { (no } \\
\text { interest, experience, } \\
\text { confidence) to } 5 \\
\text { (very interested, } \\
\text { experienced, } \\
\text { confident) }\end{array}$ & \multicolumn{5}{|c|}{$\begin{array}{l}\text { Cronbach's alpha } 0.96 \\
\text { Range possible } 16-80 \\
\text { Mid-point } 48 \\
\text { Median } 50 \\
\text { IQR 41.25-61 }\end{array}$} & \multicolumn{5}{|c|}{$\begin{array}{l}\text { Cronbach's alpha } 0.96 \\
\text { Range possible } 16-80 \\
\text { Mid-point } 48 \\
\text { Median } 38.5 \\
\text { IQR 28-46.75 }\end{array}$} & \multicolumn{5}{|c|}{$\begin{array}{l}\text { Cronbach's alpha } 0.97 \\
\text { Range possible } 16-80 \\
\text { Mid-point } 48 \\
\text { Median } 42 \\
\text { IQR 32.25-51.75 }\end{array}$} \\
\hline
\end{tabular}


Table 4. Responses to attitudinal items on aspects of research conduct $(n=124)$

\begin{tabular}{|c|c|c|c|c|c|}
\hline Statement & $\begin{array}{c}\text { Strongly } \\
\text { agree } \\
\% \text { (n) }\end{array}$ & $\begin{array}{l}\text { Agree } \% \\
\text { (n) }\end{array}$ & $\begin{array}{l}\text { Unsure\% } \\
\text { (n) }\end{array}$ & $\begin{array}{l}\text { Disagree } \\
\%(n)\end{array}$ & $\begin{array}{c}\text { Strongly } \\
\text { disagree } \\
\% \text { (n) }\end{array}$ \\
\hline \multicolumn{6}{|c|}{ Component 1 - Support and opportunities to participate in research } \\
\hline I work within a research-supportive environment & $2.4(3)$ & $23.4(29)$ & $34.7(43)$ & $29.8(37)$ & $9.7(12)$ \\
\hline I am aware of the support available for research & $2.4(3)$ & $19.4(24)$ & $28.2(35)$ & $37.1(46)$ & $12.9(16)$ \\
\hline I am aware of the research priorities for my organization & $2.4(3)$ & $14.5(18)$ & $31.5(39)$ & $36.3(45)$ & $15.3(19)$ \\
\hline I work within a research-active environment & $3.2(4)$ & $17.7(22)$ & $28.2(35)$ & $37.9(47)$ & $12.9(16)$ \\
\hline Participating in research is supported by my organization & $7.3(9)$ & $38.7(48)$ & $37.1(46)$ & $12.1(15)$ & $4.8(6)$ \\
\hline There are opportunities for me to attend research talks and seminars & $4.8(6)$ & $25.0(31)$ & $19.4(24)$ & $30.6(38)$ & $20.2(25)$ \\
\hline Participation in research is supported by my peers & $7.3(9)$ & $32.3(40)$ & $37.1(46)$ & $20.2(25)$ & $3.2(4)$ \\
\hline I am aware of training opportunities relating to research & $4.8(6)$ & $17.7(22)$ & $26.6(33)$ & $37.9(47)$ & $12.9(16)$ \\
\hline I am aware of funding opportunities relating to research & $2.4(3)$ & $12.9(16)$ & $29.0(36)$ & $38.7(48)$ & $16.9(21)$ \\
\hline I am aware of opportunities to participate in research & $4.8(6)$ & $23.4(29)$ & $27.4(34)$ & $29.8(37)$ & $14.5(18)$ \\
\hline Participating in research is supported by my line manager & $12.1(15)$ & $37.1(46)$ & $39.5(49)$ & $7.3(9)$ & $4.0(5)$ \\
\hline I have sufficient time to participate in research & $1.6(2)$ & $6.5(8)$ & $16.1(20)$ & $46.0(57)$ & $29.8(37)$ \\
\hline $\begin{array}{l}\text { There are opportunities for me to attend national and international } \\
\text { research conferences }\end{array}$ & $2.4(3)$ & $27.4(34)$ & $18.5(23)$ & $26.6(33)$ & $25.0(31)$ \\
\hline $\begin{array}{l}\text { I already have access to all of the resources I need to participate in } \\
\text { research }\end{array}$ & $2.4(3)$ & $8.9(11)$ & $39.5(49)$ & $37.9(47)$ & $11.3(14)$ \\
\hline I have clear goals for participating in research & $8.1(10)$ & $16.9(21)$ & $32.3(40)$ & $30.6(38)$ & $12.1(15)$ \\
\hline Other pharmacists I know participate in research & $11.3(14)$ & $43.5(54)$ & $22.6(28)$ & $19.4(24)$ & $3.2(4)$ \\
\hline Other health professionals participate in research & $21.0(26)$ & $54.8(68)$ & $18.5(23)$ & $4.8(6)$ & $0.8(1)$ \\
\hline \multicolumn{6}{|c|}{$\begin{array}{l}\text { Component statistics, sum of allocating } 1 \text { (strongly disagree) to } 5 \text { (strongly agree) } \\
\text { Cronbach's alpha } 0.93 \\
\text { Range possible } 17-85, \text { with } 85 \text { representing best positive attitudinal score } \\
\text { Mid-point } 51 \\
\text { Median } 47 \\
\text { IQR } 41-55\end{array}$} \\
\hline \multicolumn{6}{|c|}{ Component 2 - Motivation for and outcomes of participation in research } \\
\hline Participating in research will be of benefit to my profession & $34.7(43)$ & $59.7(74)$ & $5.6(7)$ & 0 & 0 \\
\hline Participating in research will be of benefit to my career & $27.4(34)$ & $45.2(56)$ & $15.3(19)$ & $12.1(15)$ & 0 \\
\hline Participating in research will be of benefit to patients & $33.9(42)$ & $56.5(70)$ & $8.9(11)$ & $0.8(1)$ & 0 \\
\hline Participating in research will be of benefit to my organization & $26.6(33)$ & $58.9(73)$ & $12.9(16)$ & $1.6(2)$ & 0 \\
\hline Participating in research will be of benefit to me & $24.2(30)$ & $56.5(70)$ & $14.5(18)$ & $4.0(5)$ & $0.8(1)$ \\
\hline I get/would get professional satisfaction from participating in research & $27.4(34)$ & $53.2(66)$ & $13.7(17)$ & $4.0(5)$ & $1.6(2)$ \\
\hline I am motivated to participate in research & $12.9(16)$ & $39.5(49)$ & $26.6(33)$ & $16.1(20)$ & $4.8(6)$ \\
\hline
\end{tabular}


Component statistics, sum of allocating 1 (strongly disagree) to 5 (strongly agree)

Cronbach's alpha 0.89

Range possible 7-35, with 35 representing best positive attitudinal score

Mid-point 21

Median 28

IQR 25-31

Component 3 - Individual roles and characteristics around participation in research

*I feel/would feel anxious about participating in research

\begin{tabular}{|l|c|c}
$*$ Only academics should participate in research & $0.8(1)$ & $0.8(1)$
\end{tabular}

I am confident in my ability to participate in research

I am sufficiently skilled to participate in research

I have sufficient knowledge to participate in research

I am competent to participate in research

I am able to determine my own research-related training needs

$0.8(1)$

$11.3(14)$

$41.1(51)$

$6.5(8)$

$43.5(54)$

$10.5(13)$

$41.9(52)$

$22.6(28)$

$10.5(13)$

$46.8(58)$

$33.9(42)$

Participating in research is already part of my practice

It is part of my role to participate in research

$36.3(45)$

$31.5(39)$

I support others to participate in research

$15.3(19)$

$17.7(22)$

*negative statement, reverse scored

$50.0(62)$

$19.4(24)$

$55.6(69)$

$7(12)$

Component statistics, sum of allocating 1 (strongly disagree) to 5 (strongly agree)

Cronbach's alpha 0.87

Range possible 10-50, with 50 representing best positive attitudinal score

Mid-point 30

Median 35

IOR 29-39 
Table 5. Responses to attitudinal items on aspects of applying research outcomes to practice $(n=124)$

\begin{tabular}{|c|c|c|c|c|c|}
\hline Statement & $\begin{array}{c}\text { Strongly } \\
\text { agree } \\
\%(n)\end{array}$ & $\begin{array}{l}\text { Agree } \\
\%(n)\end{array}$ & $\begin{array}{l}\text { Unsure } \\
\%(n)\end{array}$ & $\begin{array}{l}\text { Disagree } \\
\%(n)\end{array}$ & $\begin{array}{c}\text { Strongly } \\
\text { disagree } \\
\%(n)\end{array}$ \\
\hline \multicolumn{6}{|c|}{ Component 1 - Current practices and abilities to apply research outcomes } \\
\hline $\begin{array}{l}\text { I am confident in my ability to interpret and apply relevant research } \\
\text { outcomes to my practice }\end{array}$ & $11.3(14)$ & $41.9(52)$ & $23.4(29)$ & $19.4(24)$ & $4.0(5)$ \\
\hline $\begin{array}{l}\text { I am competent in my ability to interpret and apply relevant research } \\
\text { outcomes to my practice }\end{array}$ & $11.3(14)$ & $51.6(64)$ & $22.6(28)$ & $12.9(16)$ & $1.6(2)$ \\
\hline $\begin{array}{l}\text { I have sufficient knowledge to interpret and apply relevant research } \\
\text { outcomes to my practice }\end{array}$ & $10.5(13)$ & $59.7(74)$ & $16.9(21)$ & $11.3(14)$ & $1.6(2)$ \\
\hline $\begin{array}{l}\text { I am sufficiently skilled to interpret and apply relevant research } \\
\text { outcomes to my practice }\end{array}$ & $9.7(12)$ & $51.6(64)$ & $29.0(36)$ & $6.5(8)$ & $3.2(4)$ \\
\hline $\begin{array}{l}* \text { I feel/would feel anxious about interpreting and applying relevant } \\
\text { research outcomes to my practice }\end{array}$ & $7.3(9)$ & $16.9(21)$ & $21.8(27)$ & $44.4(55)$ & $9.7(12)$ \\
\hline $\begin{array}{l}\text { I already interpret and apply relevant research outcomes to my } \\
\text { practice }\end{array}$ & $12.9(16)$ & $50.8(63)$ & $15.3(19)$ & $15.3(19)$ & $5.6(7)$ \\
\hline $\begin{array}{l}\text { It is part of my role to interpret and apply relevant research outcomes } \\
\text { to my practice }\end{array}$ & $29.0(36)$ & $53.2(66)$ & $5.6(7)$ & $6.5(8)$ & $5.6(7)$ \\
\hline $\begin{array}{l}\text { I support others to interpret and apply relevant research outcomes to } \\
\text { their practice }\end{array}$ & $9.7(12)$ & $37.1(46)$ & $25.8(32)$ & $20.2(25)$ & $7.3(9)$ \\
\hline $\begin{array}{l}\text { I have clear goals for interpreting and applying relevant research } \\
\text { outcomes to my practice }\end{array}$ & $8.9(11)$ & $28.2(35)$ & $30.6(38)$ & $21.8(27)$ & $10.5(13)$ \\
\hline $\begin{array}{l}\text { * Only leaders of the profession should interpret and apply relevant } \\
\text { research outcomes to practice }\end{array}$ & $0.8(1)$ & $1.6(2)$ & $7.3(9)$ & $60.5(75)$ & $29.8(37)$ \\
\hline $\begin{array}{l}\text { I am motivated to interpret and apply relevant research outcomes to } \\
\text { my practice }\end{array}$ & $16.1(20)$ & $49.2(61)$ & $19.4(24)$ & $11.3(14)$ & $4.0(5)$ \\
\hline $\begin{array}{l}\text { * negative statement, reverse scored } \\
\text { Component statistics, sum of allocating } 1 \text { (strongly disagree) to } 5 \text { (stro } \\
\text { Cronbach's alpha } 0.91 \\
\text { Range possible } 11-55 \text {, with } 55 \text { representing best positive attitudinal sco } \\
\text { Mid-point } 33 \\
\text { Median } 40 \\
\text { IQR } 35-43.75\end{array}$ & ly agree) & & & & \\
\hline \multicolumn{6}{|c|}{ Component 2 - Consequences of applying research outcomes to practice } \\
\hline $\begin{array}{l}\text { Interpreting and applying relevant research outcomes to my practice } \\
\text { will be of benefit to my career }\end{array}$ & $22.6(28)$ & $54.0(67)$ & $12.9(16)$ & $10.5(13)$ & 0 \\
\hline $\begin{array}{l}\text { Interpreting and applying relevant research outcomes to my practice } \\
\text { will be of benefit to me }\end{array}$ & $28.2(35)$ & $59.7(74)$ & $9.7(12)$ & $2.4(3)$ & 0 \\
\hline
\end{tabular}




\begin{tabular}{|c|c|c|c|c|c|}
\hline $\begin{array}{l}\text { Interpreting and applying relevant research outcomes to my practice } \\
\text { will be of benefit to my organization }\end{array}$ & $29.8(37)$ & $58.9(73)$ & $9.7(12)$ & $1.6(2)$ & 0 \\
\hline $\begin{array}{l}\text { Interpreting and applying relevant research outcomes to my practice } \\
\text { will be of benefit to my profession }\end{array}$ & $37.9(47)$ & $53.2(66)$ & $8.9(11)$ & 0 & 0 \\
\hline $\begin{array}{l}\text { Interpreting and applying relevant research outcomes to my practice } \\
\text { will be of benefit to patients }\end{array}$ & $33.9(42)$ & $59.7(74)$ & $6.5(8)$ & 0 & 0 \\
\hline $\begin{array}{l}\text { I get/would get professional satisfaction from interpreting and } \\
\text { applying relevant research outcomes to my practice }\end{array}$ & $25.8(32)$ & $58.1(72)$ & $12.1(15)$ & $3.2(4)$ & $0.8(1)$ \\
\hline $\begin{array}{l}\text { Component statistics, sum of allocating } 1 \text { (strongly disagree) to } 5 \text { (str } \\
\text { Cronbach's alpha } 0.90 \\
\text { Range possible } 6-30, \text { with } 30 \text { representing best positive attitudinal sco } \\
\text { Mid-point } 18 \\
\text { Median } 24 \\
\text { IQR } 23-28\end{array}$ & ly agree) & & & & \\
\hline \\
\hline $\begin{array}{l}\text { Interpreting and applying relevant research outcomes to my practice } \\
\text { is supported by my organization }\end{array}$ & $9.7(12)$ & $46.0(57)$ & $29.8(37)$ & $10.5(13)$ & $4.0(5)$ \\
\hline $\begin{array}{l}\text { Interpreting and applying relevant research outcomes to my practice } \\
\text { is supported by my peers }\end{array}$ & $8.9(11)$ & $44.4(55)$ & $33.1(41)$ & $11.3(14)$ & $2.4(3)$ \\
\hline $\begin{array}{l}\text { Interpreting and applying relevant research outcomes to my practice } \\
\text { is supported by my line manager }\end{array}$ & $13.7(17)$ & $45.2(56)$ & $32.3(40)$ & $6.5(8)$ & $2.4(3)$ \\
\hline $\begin{array}{l}\text { Other pharmacists I know interpret and apply relevant research } \\
\text { outcomes to their practice }\end{array}$ & $12.1(15)$ & $47.6(59)$ & $28.2(35)$ & $9.7(12)$ & $2.4(3)$ \\
\hline $\begin{array}{l}\text { Other health professionals I know interpret and apply relevant } \\
\text { research outcomes to their practice }\end{array}$ & $19.4(24)$ & $58.9(73)$ & $17.7(22)$ & $3.2(4)$ & $0.8(1)$ \\
\hline $\begin{array}{l}\text { I already have access to all of the resources I need to interpret and } \\
\text { apply relevant research outcomes to their practice }\end{array}$ & $4.0(5)$ & $16.9(21)$ & $37.1(46)$ & $33.9(42)$ & $8.1(10)$ \\
\hline $\begin{array}{l}\text { I have sufficient time to interpret and apply relevant research } \\
\text { outcomes to their practice }\end{array}$ & $1.6(2)$ & $16.9(21)$ & $20.2(25)$ & $41.9(52)$ & $19.4(24)$ \\
\hline $\begin{array}{l}\text { Component statistics, sum of allocating } 1 \text { (strongly disagree) to } 5 \text { (str } \\
\text { Cronbach's alpha } 0.88 \\
\text { Range possible } 7-35, \text { with } 35 \text { representing best positive attitudinal sco } \\
\text { Mid-point } 21 \\
\text { Median } 23 \\
\text { IQR } 20-26\end{array}$ & ly agree) & & & & \\
\hline
\end{tabular}

